University of Nebraska - Lincoln

DigitalCommons@University of Nebraska - Lincoln

6-18-2020

\title{
Soil chemical properties after 12 years of tillage and crop rotation
}

Maysoon M. Mikha

Gary Hergert

Xin Qiao

Bijesh Maharjan

Follow this and additional works at: https://digitalcommons.unl.edu/panhandleresext

Part of the Agriculture Commons, Agronomy and Crop Sciences Commons, and the Soil Science Commons

This Article is brought to you for free and open access by the Agricultural Research Division of IANR at DigitalCommons@University of Nebraska - Lincoln. It has been accepted for inclusion in Panhandle Research and Extension Center by an authorized administrator of DigitalCommons@University of Nebraska - Lincoln. 
Soil Tillage, Conservation, \& Management

\section{Soil chemical properties after 12 years of tillage and crop rotation}

\author{
Maysoon M. Mikha ${ }^{1}$ (두 \\ ${ }^{1}$ Central Great Plains Research Station, \\ USDA-Agriculture Reserch Service, 40335 \\ County Road GG, Akron, CO 80720, USA \\ ${ }^{2}$ Agronomy-Horticulture, Panhandle \\ Research \& Extension, University of \\ Nebraska-Lincoln, 4502 Avenue I, \\ Scottsbluff, NE 69361, USA \\ ${ }^{3}$ Department of Biological Systems \\ Engineering, Panhandle Research \& \\ Extension, University of \\ Nebraska-Lincoln, 4502 Avenue I, \\ Scottsbluff, NE 69361, USA
}

\section{Correspondence}

Maysoon M. Mikha, Central Great Plains Research Station, USDA-Agriculture Reserch Service, 40335 County Road GG, Akron, CO 80720, USA.

Email:Maysoon.Mikha@usda.gov

Mention of commercial products and organization in this paper is solely to provide specific information. It does not constitute endorsement by USDA-ARS over other products and organization not mentioned. The US Department of Agriculture, Agricultural Research Service, is an equal opportunity/affirmative action employer and all agency services are available without discrimination.

\author{
Gary W. Hergert $^{2}$ () | Xin Qiao ${ }^{2,3} \quad \mid \quad$ Bijesh Maharjan $^{2}$ (c)
}

\section{1 | INTRODUCTION}

Crop rotation is a management practice that can improve land productivity, enhance economical return, sustain soil organic matter (SOM), and reduce soil erosion (Alhameid, Ibrahim, Kumar, Sexton, \& Schumacher, 2017; Gurr et al., 2016; McDaniel, Grandy, Tiemann, \& Weintraub, 2016; McDaniel, Tiemann, \& Grandy, 2014; Smith, Gross, \&

Abbreviations: CF, crop frequency; MP, moldboard plow; NT, no-tillage; POM, particulate organic matter; SOC, soil organic carbon; SOM, soil organic matter; ST, strip tillage.
Robertson, 2008). In the Western Nebraska panhandle, sugar beet and dry beans are among the economically important specialty crops that represent approximately 90\% of the sugar beet and dry beans planted in Nebraska (Groskopf et al., 2017). The inclusion of sugar beet, and dry beans in crop rotation could have a negative effect on sustaining SOM due to low plant biomass production associated with both crops (Larney, Pearson, Blackshaw, \& Lupwayi, 2017; Li, Larney, Angers, Pearson, \& Blackshaw, 2015) in addition to root removal with sugar beet (Götze et al., 2016). The common type of dry beans grown in western Nebraska produce pods close to the ground, therefore the 
conventional harvest (undercut) is used to reduce yield loss (Eckert et al., 2011; Pavlista, Hergert, Santra, \& Schild, 2013; Smith, 2004). Although, NT is possible in planting dry bean (Larney et al., 2017), conventional harvest (undercut) cause soil disturbance (Groskopf et al., 2017).

Conventional sugar beet production has used deep plowing with a moldboard plow or ripper, or chisel plowing followed by several passes of disking and leveling to create fine soil seed bed and control weeds (Afshar et al., 2019; Evens, Stevens, \& Iversen, 2009; Khan \& McVay, 2014; Smith, Yonts, Biere, \& Rath, 1995; Stevens, Evans, Jabro, \& Iversen, 2010). The historical use of full tillage requirement before planting sugar beet in addition to soil disturbances during beet harvesting has made the soil susceptible to soil organic matter (SOM) losses, reduced soil biological activity, wind erosion, loss of soil structure, and the formation of plow pans. All these factors have caused soil health degradation and decreased land sustainability (Cerdan et al., 2010; Götze et al., 2016; Hungria, Franchini, Brandao-Junior, Kaschuk, \& Souza, 2009; Stevens et al., 2010; Withers \& Lord, 2002). Crop rotation has been common practice in sugar beet production for the past 50 years (Wilson, 2013). The inclusion of cereal crops such as corn, wheat, and dry beans is common in the Rocky mountain region and helps by adding crop residue (Wilson, 2013) and reducing disease pressure (Franc, Harrveson, Kerr, \& Jacobsen, 2001).

Early research by Halvorson and Hartman (1984), in the Great Plains regions, reported the potential advantage of using no-tillage system in planting sugar beet to reduce wind erosion, conserve SOM losses, and reduce field operational cost. They also observed that sugar beet quality was often better in NT than tilled systems. However, there are some concerns that soil compaction under no-tillage restrict root growth and decrease yield (Afshar et al., 2019; Brereton et al., 1986). On the other hand, other research indicated that sugar beet roots were not influenced by soil compaction (Arvidsson, Bolenius, \& Cavalieri, 2012), which could be related to the advancement in manufacturing of modern sugar beet planters used with different cultivars under NT conditions (Afshar et al., 2019). The application of NT practice in sugar beet production is not as well studied compared with grain or energy crops (Afshar et al., 2019).

In recent years, conservation tillage practices, such as strip tillage (ST), have been implemented in sugar beet production to address some of the concerns regarding soil quality parameters and crop sustainability (Afshar et al., 2019; Tarkalson, Bjorneberg, \& Moore, 2012). Compared to moldboard plow (MP), previous research documented that sugar beet yield and sucrose content were similar for ST and MP practices; however, ST reduced runoff compared with MP (Tarkalson \& King, 2017) and ST exhibited greater

\section{Core Ideas}

- Tillage and rotation (3-yr without vs. 4-yr with sugar beet) influenced yield, soil chemistry, SOM, and POM after 12 years.

- Sugar beet and dry beans are economically important specialty crops in the Western Nebraska panhandle and are $\sim 90 \%$ of those in Nebraska.

- Full tillage before planting sugar beet plus soil disturbances during harvesting has made the soil susceptible to losses and erosion.

- Conservation tillage, such as ST, in sugar beet production can address some of the concerns regarding soil quality and crop sustainability.

- Crop rotation in sugar beet production with corn, wheat and dry beans may help by adding crop residue and reducing disease pressure.

yield and sugar recovery compared with MP under stressful conditions such as wind storms (Evens et al., 2009).

Crop rotation can break pest life cycles, reduce weed problems, control soil erosion, enhance soil nutrient dynamics, improve productivity, and increase overall net returns (Gurr et al., 2016; McDaniel et al., 2016; Smith et al., 2008). In addition, crop rotation can enhance soil organic carbon (Alhameid et al., 2017; McDaniel et al., 2014), increase total nitrogen (N), improve microbial activity (McDaniel et al., 2014), and $\mathrm{N}$ inputs via $\mathrm{N}$-fixation when legumes are included in the rotation (Land et al., 2017). Aboveground and belowground biomass production could positively impact SOM content and microbial activity (Havlin, Kissel, Maddux, Claassen, \& Long, 1990; Karlen et al., 1994). Crop rotation helps with soil nutrients cycling because different crops have different nutritional needs and different nutrient absorption abilities (Alves et al., 2019; Tiecher, Calegari, Caner, \& Rheinheimer, 2017). Further, different crops in rotation with different yield potentials, root morphologies, and residue inputs, all of which can benefit soil nutrients dynamics (Russelle \& Birr, 2004), soil quality, and land sustainability (Karlen et al., 2006).

Since specialty crops (sugar beet and dry bean) are important for the economies returns of western Nebraska, soil disturbance during planting with sugar beet and during harvesting with both crops is inevitable. Therefore, the objectives of this study were to evaluate the influence of tillage (MP, ST, and NT) and crop rotations in 3-yr rotation without sugar beet vs. 4-yr rotation with sugar beet on (1) crop yield; (2) soil chemical properties; and (3) soil organic 
matter (SOM) and particulate organic matter (POM) after 12 yrs of management. We hypothesize that yield and other soil parameters studied will be influenced by tillage and crop rotation (crop frequency $[\mathrm{CF}]$ and crop phases) after 12 yrs of management. In this study, we present the first report of soil chemical properties and SOM under different crop rotation and tillage practices that will be used as baseline data for future research at this site.

\section{2 | MATERIALS AND METHODS}

\subsection{Site and treatment descriptions}

The study was initiated in 2007 at the University of Nebraska-Lincoln Panhandle Research and Extension Center near Scottsbluff, NE ( $41^{\circ} 52^{\prime} 2^{\prime \prime}$ N, 103 $33^{\circ} 39^{\prime \prime}$ W). The elevation of the station is approximately $1,186 \mathrm{~m}$ above sea level and a 30-yr mean annual precipitation of $332 \mathrm{~mm}$ (High Plains Regional Climate Center, 2020). The study was conducted on a Tripp very find sandy loam (coarsesilty, mixed, superactive, mesic Aridic Haplustolls) soil with 1 to $3 \%$ slope.

Two crop rotation sequences were evaluated, where corn (C; Zea mays L.) and dry bean (DB; Phaseolus vulgaris L.) were organized in 3-yr (DB-C-C) rotation without sugar beet $(\mathrm{SB})$ and in 4-yr (DB-C-SB-C) rotation with sugar beet addition. In both rotations each phase of rotation was present each year. Crop frequency (CF) was evaluated for 3 -yr and 4-yr rotations, where corn CF was 66\% in 3-yr (DB$\mathrm{C}-\mathrm{C})$ rotation and $50 \%$ in 4-yr (DB-C-SB-C) rotation; dry bean $\mathrm{CF}$ was $33 \%$ in 3-yr (DB-C-C) rotation and $25 \%$ in 4-yr (DB-C-SB-C) rotation; and sugar beet CF was only at $25 \%$ in 4-yr (DB-C-SB-C) rotation (Table 1). A total of seven crop phases were evaluated, depending on rotation and sequence order (Table 1). Target seeding rates were 14,600 seeds ha ${ }^{-1}$ for corn; 22,700 seeds ha ${ }^{-1}$ for sugar beet; and 37,200 seeds ha ${ }^{-1}$ for dry bean. The same rates of urea (46-0-0) and mono-ammonium phosphate (11-52-0) were used for all three tillage systems within a crop. Fertilizer needs were determined each year based on soil tests as per recommendation and soil $\mathrm{N}$ content from the previous credit especially after dry bean (Hergert, 2012; Hergert \& Schild, 2013; Shapiro, Ferguson, Wortmann, Maharjan, \& Krienke, 2019).

The experiment was organized as a split plot design with three replicates. The study site consists of 63 plots. Tillage treatments represent the whole plot. The crop phases were randomized as subplots within each whole plot (tillage). Individual subplots were $6.7 \mathrm{~m}$ wide by $65.2 \mathrm{~m}$ long. Tillage practices including conventional full-inversion tillage that consisted of moldboard plowing (MP) up to 30-cm depth; strip tillage (ST) that consisted of sub-surface tillage on
TA B LE 1 Description of cropping frequency and rotation phases. All the rotation accrued with each tillage practice (moldboard plow, MP; strip tillage, ST; and no-tillage, NT) and various crop rotation with different rotation phase and frequency. The Bold crop represents the crop that was planted in 2018 before 2019 spring soil sampling

\begin{tabular}{|lc|}
\hline Rotation phase as was planted in 2018 & $\begin{array}{c}\text { Cropping } \\
\text { frequency } \\
(\mathbf{C F})^{\mathrm{a}}\end{array}$ \\
\hline Corn-Corn-Dry Bean (C-C-DB) & $66 \%$ \\
\hline Dry Bean-Corn-Corn (DB-C-C) & $33 \%$ \\
\hline Corn-Dry Bean-Corn (C-DB-C) & $66 \%$ \\
\hline Sugar Beet-Corn-Dry Bean-Corn (SB-C-DB-C) & $25 \%$ \\
\hline Corn-Sugar Beet-Corn-Dry Been (C-SB-C-DB) & $50 \%$ \\
\hline Dry Bean-Corn-Sugar Beet-Corn (DB-C-SB-C) & $25 \%$ \\
\hline Corn-Dry Bean-Corn-Sugar Beet (C-DB-C-SB) & $50 \%$ \\
\hline
\end{tabular}

${ }^{a}$ Represent the frequency of the specific crop accruing in each rotation

seeding rows at $30-\mathrm{cm}$ depth with $1.5-\mathrm{cm}$ wide shanks; and no-tillage (NT). Harvest operation for sugar beet involved considerable soil disturbance to $20-\mathrm{cm}$ depth each fall.

Weeds were controlled with herbicide. The herbicide types and rates used as recommended and as reported by Gaussoin, Kappler, Klein, Knezevic, and Lyon (2005). For corn, a pre-mixture herbicide of glyphosate [isopropylamine salt of $N$-(phosphonomethyl) glycine] at $1.12 \mathrm{~kg}$ ae ha ${ }^{-1}$ and dicamba (3, 6-dichloro-2-methoxybenzoic acid) plus diflufenzopyr (sodium 2-(1-(4(3,5-difluorophenyl) semicarbazono) ethyl) nicotinate) at $365 \mathrm{ml} \mathrm{ha}^{-1}$ was applied post plant emergence. Corn under NT received an additional pre-planting herbicide mix of glyphosate at $1.12 \mathrm{~kg}$ ae $\mathrm{ha}^{-1}$ and saflufenacil ( $N^{\prime}$-\{2-Chloro-4-fluoro-5-[1,2,3,6-tetrahydro-3-methyl-2,6dioxo-4-(trifluoromethyl)pyrimidin-1-yl]benzoyl $\}-N$-isopropyl- $N$-methylsulfamide) plus dimethenamid-P (2Chloro- $N$-(2,4-dimethyl-3-thienyl)- $N$-(2-methoxy-1-methylethyl) acetamide) at $1.02 \mathrm{~L} \mathrm{ha}^{-1}$. In bean, a preemergence herbicide mix of $1.02 \mathrm{~L} \mathrm{ha}^{-1}$ of dimethenamid$\mathrm{P}$ (2-Chloro- $N$-(2,4-dimethyl-3-thienyl)- $N$-(2-methoxy-1methylethyl) acetamide) and $2.34 \mathrm{~L} \mathrm{ha}^{-1}$ of pendimethalin (3,4-Dimethyl-2,6-dinitro- $N$-pentan-3-yl-aniline) and postemergence mix of imazamox (3-Quinolinecarboxylic acid, 2-[4,5-dihydro-4-methyl-4-(1-methylethyl)-5-oxo-1H-imidazol-2-yl) at $0.29 \mathrm{~L} \mathrm{ha}^{-1}$ and bentazon (3-Isopropyl-1H2,1,3-benzothiadiazin-4(3H)-one 2,2-dioxide) at $1.17 \mathrm{~L} \mathrm{ha}^{-1}$ were applied. Dry bean and sugar beet under NT received an additional pre-planting herbicide of glyphosate at $1.12 \mathrm{~kg}$ ae ha ${ }^{-1}$. Quizalofop (Ethyl (2R)-2-[4-[(6-chloro-2quinoxalinyl) oxy] phenoxy] propanoate) was applied at rate of $0.58 \mathrm{~L} \mathrm{ha}^{-1}$ to dry bean and sugar beet fields in the years when volunteer corn emerged from previous rotation. 
In this study, crop yield associated with different crop rotations planted in 2018 was evaluated. Corn was harvested with a 12-row harvester combine (John Deere 9500 with Ag leader Insight yield monitor). Dry bean was handharvested (for yield evaluation) by removing plants from 2center rows at 3-m long for each plot and then threshed for bean yield. The entire dry bean plots were then harvested with combine (John Deere 9500 with Ag leader Insight yield monitor). For sugar beet, 2-center rows of the plot were harvested with a small two-row beet harvester/digger (a modified Hesston 565 with weigh basket).

\section{2 | Soil sampling and analyses}

Soil samples were taken in April 2019 before planting and before any spring field operation. Two $2.5-\mathrm{cm}$ dia. cores (0-20 cm depth) were collected in each treatment plot using a hydraulic probe (Giddings, Inc. Windsor, $\mathrm{CO}$ ) and composited by plot for chemical analysis. Another two $2.5-\mathrm{cm}$ dia. cores were taken at $0-10 \mathrm{~cm}$ and $10-20 \mathrm{~cm}$ for particulate organic matter (POM) evaluation. Soil samples, were collected between crop rows, purposely avoiding the wheel-trafficked areas. Soil samples were air-dried, sieved through a 2-mm screen, and tested for different soil chemical properties (Ward Laboratory, Kearney, NE). Electrical conductivity (EC) and acidity $(\mathrm{pH})$ were evaluated using a glass electrode with a 1:1 soil/water ratio (Manjula, Stecker, \& Sun, 2006; McLean, 1982; Whitney, 1998a). Soil phosphorus (P) was determined using the Olsen sodium bicarbonate method (Frank, Beegle, \& Denning, 1998), which is the optimal P method for the alkaline soils. Soil extractable cations such as potassium $(\mathrm{K})$, calcium $(\mathrm{Ca})$, magnesium $(\mathrm{Mg})$, and sodium $(\mathrm{Na})$ were extracted with a neutral $\left(\mathrm{NH}_{4} \mathrm{OAc}\right) 1 \mathrm{~N}$ ammonium acetate (Warncke \& Brown, 1998) and the extract was analyzed using an ICAP (Inductively Coupled Argon Cooled Plasma) Spectrometer (Thermo Fisher Scientific Inc., Waltham, MA). Soil sulfur (S) was evaluated using Mehlich III and analyzed with ICAP (Combs, Denning, \& Frank, 1998; Geldeman \& Beegle, 1998). Soil zinc (Zn) was evaluated using DTPA (diethylenetriaminepentaacetic acid) extraction procedure and analyzed with ICAP (Lindsay \& Norvell, 1978; Whitney, 1998b). Soil extract with $1 M \mathrm{KCl}$ was used to for inorganic $\mathrm{N}\left(\mathrm{NO}_{3}{ }^{-}\right)$evaluation. Soil organic carbon (SOC) was evaluated after removing soil carbonates by adding $6 \%$ sulfuric acid to a subsample $(0.1$ to $1.0 \mathrm{~g})$ of a finely ground air-dried soil, followed dry combustion at $950{ }^{\circ} \mathrm{C}$ using a LECO CHN-2000 (Skjemstad \& Baldock, 2007).

Particulate organic matter ( $\mathrm{POM})$ was evaluated in the soil samples taken from the surface $0-10 \mathrm{~cm}$ and $10-20 \mathrm{~cm}$ depths using the procedure outlined by Cambardella, Gajda, Doran, Wienhold, and Kettler (2001). Briefly, 30 g of air-dried soil was dispersed in $90 \mathrm{ml}$ of sodium hexametaphosphate at $5 \mathrm{~g} \mathrm{~L}^{-1}$ and shaken on a reciprocal shaker for $16 \mathrm{~h}$. The dispersed soil was passed through sieves with mesh sizes of $53-\mu \mathrm{m}$ and washed with distilled water (DI). The POM plus sand collected was dried to a constant weight at $50{ }^{\circ} \mathrm{C}$. The sand-free POM mass (Sandfree POM) was evaluated by loss-on-ignition (LOI) procedure using mass difference after $4 \mathrm{~h}$ in a muffle furnace at $450^{\circ} \mathrm{C}$. The POM is reported as grams of POM per kilogram of soil using the equation outlined by Mikha et al. (2006) as follows:

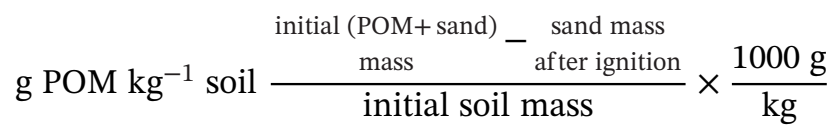

\section{3 | Statistical analysis}

Tillage and rotation phase effects on soil chemical properties at $0-20 \mathrm{~cm}$ depths were tested with an analysis of variance using PROC MIXED procedure of SAS ver. 9.2 (SAS Institute Inc. 2006). Tillage (whole plot), rotation phase (split plot), and soil depth (split-split plot) were analyzed as fixed effects, and replication was analyzed as a random effect. Separate analysis of variance (ANOVA) was conducted for each crop to compare the effects of tillage, crop rotation, and the phase of each crop on yield. The protected F-test was used to explain multiple comparisons of means using treatment differences. All results were considered significantly different at $P<.05$, unless noted otherwise.

\section{3 | RESULTS AND DISCUSSION}

\section{1 | Weather factors}

Annual precipitation of $539 \mathrm{~mm}$ in 2018 (Figure 1) was higher than the 30-yr average precipitation of $331.5 \mathrm{~mm}$ by approximately $63 \%$ (208 $\mathrm{mm}$ ), primarily related to higher rainfall in May and July. The precipitation during May $(231 \mathrm{~mm})$ of 2018 exceeded the 30-yr May average precipitation $(64.3 \mathrm{~mm}$ ) by $167 \mathrm{~mm}$ which represents approximately $259 \%$. Similarly, the precipitation during July $(111 \mathrm{~mm})$ of 2018 exceeded the 30-yr July average precipitation (46 mm) by $65 \mathrm{~mm}$ which represents approximately 141\%. These high monthly rainfall amounts were not mitigated by lower than usual monthly precipitation in August and September, which were $74 \%$ (24 mm) and in September by an average of $89 \%(25 \mathrm{~mm})$ below the 30 -yr monthly mean, respectively. The average ambient temperature throughout the 2018 was almost the same (within 1 to $2{ }^{\circ} \mathrm{C}$ ) as the normal temperature of the 30-yr average (Figure 1). Although 


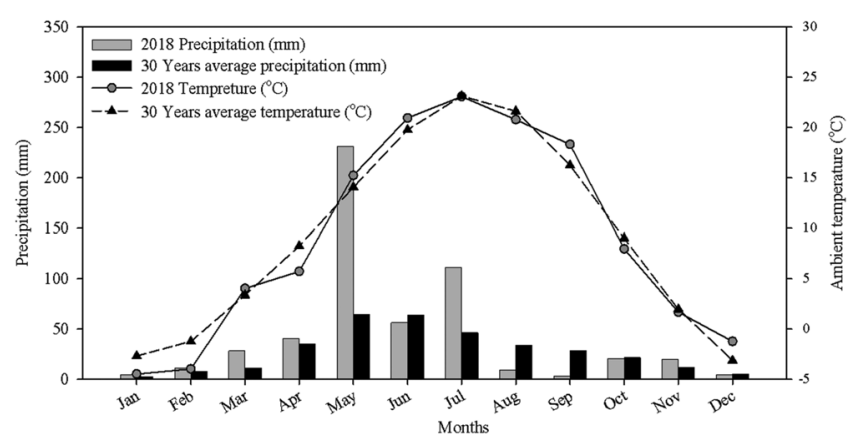

F I G U R E 1 Thirty years and 2018 precipitation ( $\mathrm{mm}$ ) in addition to 30 -yr and 2018 ambient temperature $\left({ }^{\circ} \mathrm{C}\right)$ during crop growing seasons. The bars represent the precipitation while the lines represent the ambient temperature

the study site is irrigated, throughout the majority of the crop growing season, the 2018 exhibited equal or higher precipitations than the 30-yr average. Therefore, the crops were irrigated (as needed) to fulfill the crop water need mainly during August and September.

\section{2 | Crop yield}

Crop yield varied depending on the crop phase (corn, dry bean, and sugar beet); $\mathrm{CF}$ (dry bean at $25 \%$ and $33 \%$, corn at $50 \%$, and $66 \%$, and sugar beet at $25 \%$ ) associated with for 3-yr rotation (DB-C-C) without sugar beet and 4-yr (DB-C-SB-C) rotation with sugar beet; and previous crop phase in rotation. In this study, the statistical analysis for each crop's yield was analyzed separately to prevent the high yielded crop, such as sugar beet, to influence the statistical difference of corn and dry bean crop in rotation (Figure 2). Corn grain yield was not influenced by tillage practices, but it was influenced by rotation phase $(P<.0001)$. The 3-yr rotation of corn following dry bean $(\mathrm{C}-\mathrm{C}-\mathrm{DB})$ at $\mathrm{CF}=66 \%$, exhibited the highest yield when compared with other corn yields in other rotations $(P<.0001)$. However, the corn yield following corn in the same rotation (C-C-DB) was lower by $30 \%$ which represents $4.7 \mathrm{Mg} \mathrm{ha}^{-1}$. The reduction in corn yield following corn could be potentially related to greater insect and weed infestation when compared with biennial corn or another crop (Daberkow, Payne, \& Schepers, 2008). The corn yield in the 4-yr rotation with $\mathrm{CF}=50 \%$ was influenced by the previous crop in rotation, such that corn yield following dry bean in C-DB-C-SB rotation was approximately $14 \%$ which represents $1.8 \mathrm{Mg} \mathrm{ha}^{-1}$ greater than corn yield following sugar beet. The low corn yield following sugar beet could be related to the sugar beet harvest procedure that consisted of considerable soil manipulation such as SOM losses, reduced soil biological activity, the formation of plow pans that could damage soil quality and land sustain-

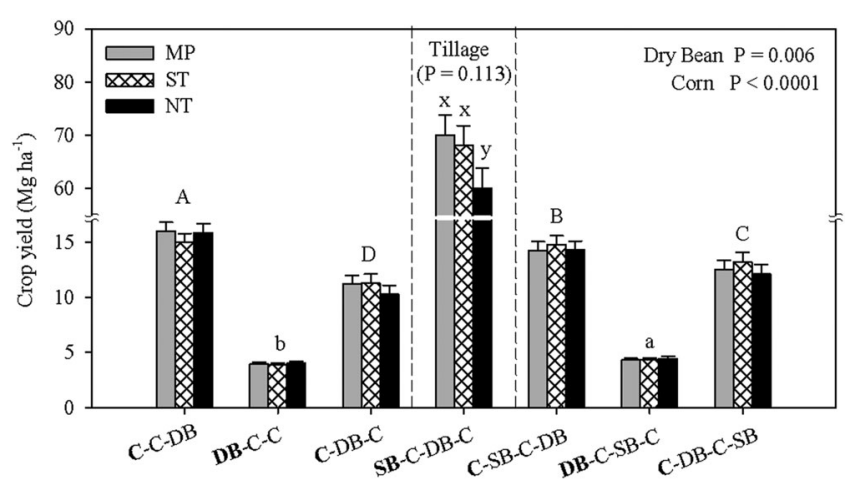

F I G U R E 22019 crop yields at various crop rotations with different rotation phases and cropping frequency: dry bean (DB), corn (C), and sugar beet (SB) as influenced by tillage practices (moldboard plow, MP; strip tillage, ST; and no-tillage, NT). The lowercase letters $\mathrm{a}$ and $\mathrm{b}$ represent (ANOVA) significant $(P=.006)$ differences between dry bean crop in rotations. The lowercase letters $\mathrm{x}$ and $\mathrm{y}$ represent (ANOVA) significant $(P=.113)$ differences among tillage practices associated with sugar beet crop. The uppercase letters represent (ANOVA) significant $(P<.0001)$ differences among corn crop in rotations. The error bars represent the standard deviation among the means for each crop. The bolded crop represents the crop phase that was planted in 2018

ability (Cerdan et al., 2010; Götze et al., 2016; Hungria et al., 2009; Stevens et al., 2010; Withers \& Lord, 2002) and negatively influence the subsequent corn yield. Dry bean yield was affected only by the rotation type $(P=.006)$, where yield in the 3-yr rotation (DB-C-C) was lower (Figure 2) than the 4-yr rotation (DB-C-SB-C) by an average of $9.4 \%$ which represents $0.4 \mathrm{Mg} \mathrm{ha}^{-1}$.

Since the sugar beet crop was planted in one rotation (C-DB-C-SB), the different tillage practices are the only factors that could influence the sugar beet production. Analysis of variance showed that sugar beet yield was influenced by tillage practices at $P=.113$ (Figure 2). The sugar beet yield was greater by an average of $17 \%$ which represents $10 \mathrm{Mg} \mathrm{ha}^{-1}$ for MP and by $13 \%$ which represents $8 \mathrm{Mg} \mathrm{ha}^{-1}$ for ST when compared with NT practices (Figure 2). The increase in sugar beet yield associated with MP and ST could be related to soil homogenizing, proper mixing, for seed bed preparation, and possible breaking of the compacted layer generated from previous sugar beet harvesting (Afshar et al., 2019; Evens et al., 2009, Stevens et al., 2010, Khan \& McVay, 2014). Whereas, in NT, soil was not tilled before sugar beet planting and the compacted layer, that may exist, could negatively affect subsequent sugar beet yield (Afshar et al., 2019; Brereton et al., 1986). Over all, the data generated from this study partially supported our hypothesis where corn and dry bean yields were influenced by the previous crop in rotation, but not by tillage or $\mathrm{CF}$, while sugar beet yield was influenced by tillage practices at $P=.113$. 
TA B L E 2 Statistical mean values of soil chemical properties at 0-20 cm depth from spring of 2019 sampling influenced by different tillage (moldboard plow, MP; strip tillage, ST; and no-tillage, NT) and various crop rotation with different rotation phase and frequency: dry bean (DB), corn (C), sugar beet (SB). The Bold crop represents the phase planted in 2018 before 2019 spring soil sampling

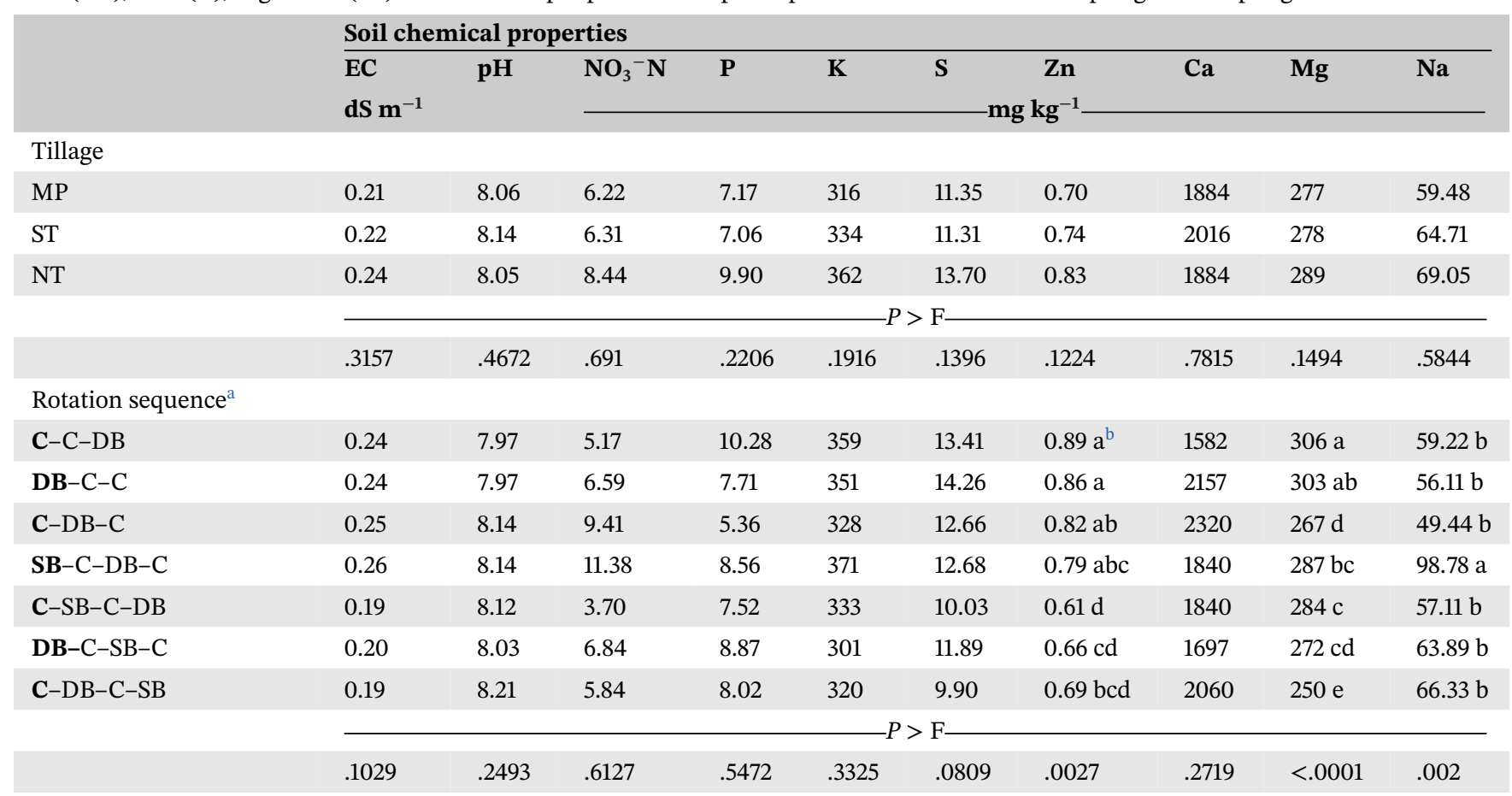

Rotation phase $\times$ Tillage

$3495-9936-2052-87$

.8307

$.9707 \quad .2582$

.691

${ }^{a}$ Represents rotation sequence: Corn-Corn Dry Bean; Dry Bean-Corn-Corn; Corn-Dry Bean-Corn; Sugar Beet-Corn-Dry Bean-Corn; Corn-Sugar Beet-Corn-Dry Bean; Dry Bean-Corn-Sugar Beet-Corn; Corn-Dry Bean-Corn-Sugar Beet

${ }^{\mathrm{b}}$ The lowercase letters represent (ANOVA) significant $(P<.05)$ differences

\section{3 | Soil chemical properties}

Soil chemical properties evaluated in this study such as, $\mathrm{EC}, \mathrm{pH}$, and extractable $\mathrm{NO}_{3}, \mathrm{P}, \mathrm{K}, \mathrm{S}, \mathrm{Zn}, \mathrm{Ca}, \mathrm{Mg}$, and $\mathrm{Na}$ were not influenced by tillage practices or the crop rotation $\times$ tillage interaction (Table 2). After 12 yrs of different management practices, soil $\mathrm{pH}$ was similar across all treatments (8.1), despite mineral nitrogen additions over the period of 12 yrs. Obour, Mikha, Holman, and Stahlman (2017) reported that after 50-yr of different tillage and $\mathrm{N}$ rates, a significant reduction in soil $\mathrm{pH}$, across tillage, was observed with a high $\mathrm{N}$ rate at the surface $0-7.5 \mathrm{~cm}$ depth, but not below this depth. They also reported that the surface (0-7.5 cm depth) exhibit a decrease in soil $\mathrm{pH}$ by an average of 0.25 units that was associated with conventional tillage and MP treatments. In this study, the initial (baseline) soil $\mathrm{pH}$ and other chemical properties are not available; therefore, there is no basis of comparison of treatment effects on soil $\mathrm{pH}$ and other soil chemical properties measured over time. In addition, sampling at small depth increments $(5-\mathrm{cm}$ or $10-\mathrm{cm}$ increments) with small soil mass (Haruna \& Nkongolo, 2019; Mikha, Benjamin, Stahlman, \& Geier, 2014; Obour et al., 2017) could reveal the treat- ments differences when compared with sampling at the 20$\mathrm{cm}$ increments. The dilution effect for soil nutrients associated with $0-20 \mathrm{~cm}$ sampling depth could eliminate the treatment differences due to the larger soil mass sampled.

In the present study, the variability in soil chemical properties among the treatments could contribute to eliminating the influence of tillage and crop $\times$ tillage interaction on soil chemical properties. The observed results are supported by previous research that reported some soil nutrients could be leached below the $20 \mathrm{~cm}$ depth (Maltas, Charles, Jeangros, \& Sinaj, 2013) and crop nutrient uptake and grain nutrient removal could eliminate the differences in soil chemical properties due to management (Maltas et al., 2013; Sistani, Simmons, Warrem, \& Higgins, 2017). Maltas et al. (2013) also concluded that the 12 yrs study period was not sufficient to observe significant differences in soil chemical properties and that a longer period of time was needed to detect the differences.

In contrast to other soil fertility metrics, $\mathrm{Zn}, \mathrm{Mg}$, and Na were significantly influenced by crop rotation (Table 2). Since no nutrients other than $\mathrm{N}$ and $\mathrm{P}$ were added to this study site, the differences in soil $\mathrm{Zn}, \mathrm{Mg}$, and $\mathrm{Na}$ among the crop rotation could be related to crop uptake need of 


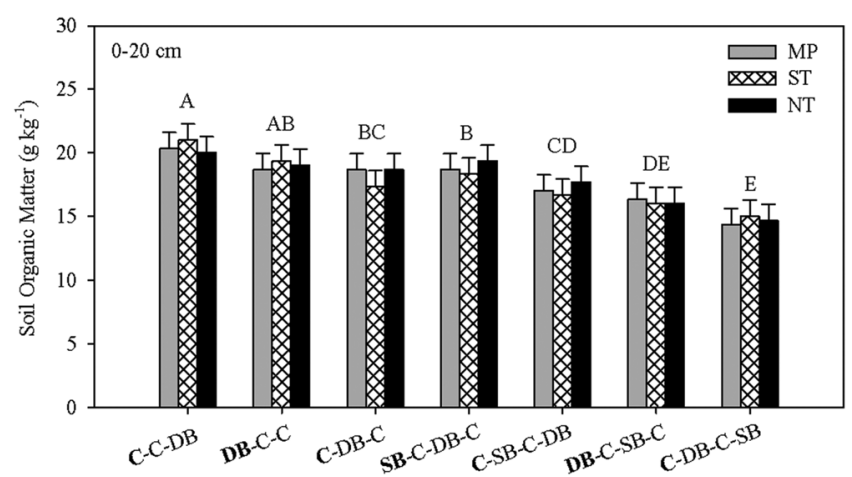

F I G U R E 3 Soil organic matter (SOM) at 0-20 cm depth influenced by crop rotations with different rotation phases and cropping frequency: dry bean (DB), corn (C), sugar beet (SB) and tillage practices (moldboard plow, MP; strip tillage, ST; and no-tillage, NT). The uppercase letters represent (ANOVA) significant $(P<.05)$ differences among rotation phases. The error bars represent the standard deviation among the means. The bolded crop represents the crop phase that was planted in 2018 before 2019 spring soil sampling

these nutrients, to the soil nutrients abundance, or to the nutrients content in the water used for irrigation. Larney et al. (2017) observed that timing and amount of irrigation could influence soil electrical conductivity (EC), thus soil nutrients content. They also reported that latter irrigation during August and September could increase soil EC and nutrient dynamics especially under sugar beet due to the crop deep roots that can alter surface EC levels. In our study, a narrow range of soil EC was observed among the crop rotations (Table 2). The higher amount of $\mathrm{Na}$ after sugar beet, compared with other crop phase, could be related to the sugar beet's deep root nutrients extract causing the soil nutrients to move up to the near surface layers (Larney et al., 2017). The inclusion of sugar beet in C-DB-C-SB rotation could reduce the advantage of continuous NT practice in maintaining surface residue due to soil disturbance during sugar beet harvest, up to $20-\mathrm{cm}$, every fourth year. The soil was also disturbed, by approximately $5-7 \mathrm{~cm}$, during dry bean harvest operation with $\mathrm{C}-\mathrm{DB}-\mathrm{C}-\mathrm{SB}$ and $\mathrm{C}-\mathrm{C}-\mathrm{DB}$ rotations which reduced the advantage of NT in maintaining soil surface residue.

The SOM (Figure 3) and SOC (Figure 4) were not influenced by tillage or by tillage $\times$ crop rotation interaction, but they were influenced by crop rotation $(P<.0001)$. Previous research documented the increased in SOM with NT and reduced tillage at the surface $30 \mathrm{~cm}$ depth when compared with MP treatments after 50 yrs of management (Obour et al., 2017). In this study, the NT is not a typical zero disturbance practice due to dry bean and sugar beet crops in rotation. As previously mentioned, harvesting sugar beet and dry bean caused soil disturbance every other year with C-DB-C-SB rotation and once every three years with C$\mathrm{C}-\mathrm{DB}$ rotation. Therefore, the NT data generated with cur-

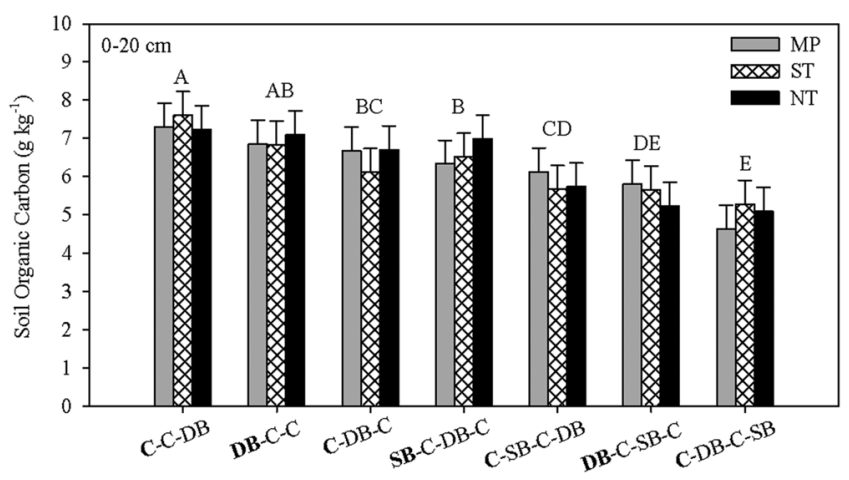

F I G U R E 4 Soil organic carbon (SOC) at 0-20 cm depth influenced by crop rotations with different rotation phases and cropping frequency: dry bean (DB), corn (C), sugar beet (SB) and tillage practices (moldboard plow, MP; strip tillage, ST; and no-tillage, NT). The uppercase letters represent (ANOVA) significant $(P<.05)$ differences among rotation phases. The error bars represent the standard deviation among the means. The bolded crop represents the crop phase that was planted in 2018 before 2019 spring soil sampling

rent rotation is different than the NT data generated from the previous research with grain crop. The NT in grain crop research is associated with zero soil disturbances that occur only with the corn crop in current rotation studied. In this study, the lack of tillage influence on SOM and SOC could be related to (1) the sampling depth of $20 \mathrm{~cm}$ which was shallower than the MP operation as the surface layer with its residue was inverted to $30-\mathrm{cm}$ depth; or (2) the big pool size of SOM and SOC that eliminate the observed changes due to tillage treatments.

The corn following dry bean in C-C-DB rotation exhibits the highest SOM $39 \%\left(5.8 \mathrm{~g} \mathrm{~kg}^{-1}\right)$ and SOC $48 \%$ $\left(2.4 \mathrm{~g} \mathrm{~kg}^{-1}\right)$ when compared with corn (C-DB-C-SB) after sugar beet (Figures 3 and 4 ) which corresponds to the high yield observed with corn (Figure 2). Previous research documented that SOM content can be influenced by plant residue input and residue decomposition (Curtin, Beare, \& Hernandez-Ramirez, 2012). The lowest SOM and SOC were observed with corn following sugar beet in 4-yr (C-DB-C-SB) rotation, where the SOM and SOC associated with other rotations were intermediate between dry bean in 3-yr (DB-C-C) rotation and dry bean in 4-yr (DB-C-SB-C) rotation (Figures 3 and 4). Our data shows that $\mathrm{SOM}$ and $\mathrm{SOC}$ could be influenced by the rotation phase at the time of sampling, but not with the CF. The low amount of SOM and SOC associated with corn crop following sugar beet in the 4-yr (C-DB-C-SB) rotation could be related to the low corn yield and previous soil manipulation associated with sugar beet harvesting. However, the SOM and SOC were intermediate during the second year crop (DB) following SB of the same 4-yr (DB-C$\mathrm{SB}-\mathrm{C}$ ) rotation, where the third crop (corn) of the same rotation (C-SB-C-DB) was significantly different from the 
first corn crop following SB. The significant amount of SOM and SOC associated with 4-yr rotation during the $\mathrm{SB}$ phase (SB-C-DB-C) could be related to three years of SOM and SOC build up during the SB absent. The NT practice and the corn crop reside returned significantly contributed to enhance SOM and SOC in this 4-yr (SB$\mathrm{C}-\mathrm{DB}-\mathrm{C}$ ) rotation. This observation was supported by the highest amount of SOM and SOC in 3-yr rotation without inclusion of SB crop (Figures 3 and 4). In our data, the SOM and SOC were slightly improving as the time span from sugar beet crop increased (during the second and third years of the rotation). However, the cycle repeat itself every 4 yrs when corn was planted after sugar beet and the reduction in SOM and SOC could be observed (Figures 3 and 4). Previous research documented that including dry bean as a legume within the crop rotation could increase $\mathrm{N}$ availability, enhance crop residue decomposition, and enhance SOM or SOC (Bowren et al., 1995; Castro, Crusciol, Calonego, \& Rosolem, 2015; Ohtonen, Aikio, \& Vare, 1997). The data generated from this study partially supported our hypothesis that soil chemical properties were influenced by the previous crop in rotations and $\mathrm{CF}$, but not with tillage.

\subsection{Particulate organic matter (POM)}

Soil POM is the labile fraction of SOM and considered to be the SOM pool most sensitive to management practices (Castro et al., 2015; Gregorich, Cartter, Angers, Monreal, \& Ellert, 1994; Li et al., 2018). At the 0-10 cm (Figure 5), soil POM was significantly influenced by tillage $(P=.0018)$, rotation phase $(P<.0001)$, tillage $\times$ rotation phase interaction $(P<.0001)$. During 3 -yr rotation phases, a significant tillage interaction was observed, where POM was significantly higher in NT compared with ST and MP (Figure 5). However, the tillage appeared to have no influence on POM at any rotation phase in the 4-yr rotation. The inclusion of SB and DB in 4-yr rotation could eliminate the benefits of NT and ST on POM amount due to soil disturbance associated with sugar beet seedbed preparation and harvest operations for SB and DB crops. The interaction of tillage $\times$ rotation phase reflected that $\mathrm{NT}$ corn $(\mathrm{CF}=66 \%)$ in 3-yr rotation (C-C-DB) contained the highest amount of POM $\left(18.7 \pm 1.2427 \mathrm{~g} \mathrm{~kg}^{-1}\right)$ when compared with corn in 4-yr rotation (C-DB-C-SB), where POM amount was $7.7 \mathrm{~g} \mathrm{~kg}^{-1}$. The ST corn $(\mathrm{CF}=66 \%)$ in 3-yr rotation $(\mathrm{C}-$ $\mathrm{C}-\mathrm{DB})$ contained the second highest amount of POM (13.4 $\left.\mathrm{g} \mathrm{kg}^{-1}\right)$ when compared with corn in 4-yr rotation (C-DB-C-SB), where POM amount was $6.2 \mathrm{~g} \mathrm{~kg}^{-1}$. The lowest POM amount was with NT dry bean $(\mathrm{CF}=33 \%)$ in 3-yr rotation $\left(12.2 \mathrm{~g} \mathrm{~kg}^{-1}\right)$ followed with ST dry bean $\left(8.05 \mathrm{~g} \mathrm{~kg}^{-1}\right)$ compared with 4-yr rotation $(\mathrm{CF}=25 \%)$ of

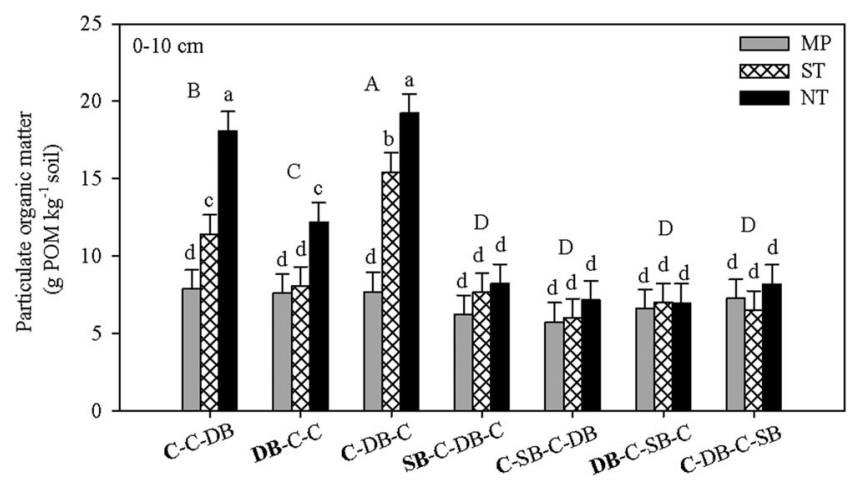

F I G U R E 5 Particulate organic matter (POM) at 0-10 cm depth (tillage $\times$ rotation phase interaction) influenced by crop rotations with different rotation phases and cropping frequency: dry bean (DB), corn (C), sugar beet (SB) and tillage practices (moldboard plow, MP; strip tillage, ST; and no-tillage, NT). The lowercase letters represent (ANOVA) significant $(P<.05)$ differences among tillage practices. The uppercase letters represent (ANOVA) significant $(P<.05)$ differences among the rotation phases. The error bars represent the standard deviation among the means. The bolded crop represents the crop phase that was planted in 2018 before 2019 spring soil sampling

NT and ST dry bean $\left(7.0 \mathrm{~g} \mathrm{~kg}^{-1}\right)$. The POM amount with MP was the lowest value among all the rotation studied. The POM amount with sugar beet was also among the lowest values compared with corn and dry bean (Figure 5). Our data indicates that increasing corn frequency in rotation increased soil POM which could be related to higher corn biomass production compared with sugar beet and dry bean. In addition, this 3-yr rotation $\mathrm{C}-\mathrm{C}-\mathrm{DB}$ could benefit from NT advantage in maintaining surface residue during corn phases, because soil disturbance is limited to dry bean harvest, at 5-7 $\mathrm{cm}$ depth, every $3 \mathrm{yr}$. This data agrees with previous research that documented the increase in soil POM with maintaining surface residue and reducing soil disturbance (Cambardella \& Elliott, 1993; Li et al., 2018; Mikha, Benjamin, Vigil, \& Nielson, 2010; Mikha, Vigil, \& Benjamin, 2013).

In contrast to the surface $0-10 \mathrm{~cm}, P O M$ at the $10-20 \mathrm{~cm}$ depth was significantly influenced by tillage $(P=.0185)$ and rotation phases $(P<.0001)$, but not by tillage $\times$ rotation phase interaction $(P=.1438)$. In general, soil POM was significantly affected by depth $(P=.0066)$ and by tillage $\times$ rotation phase $\times$ depth interaction $(P<.0001)$. Average across tillage, soil POM at any cropping frequency and rotation phase was significantly higher at $0-10 \mathrm{~cm}$ when compared with 10-20 cm depth (Figure 6). The average across tillage and rotation phases, POM was greater by approximately $74 \%$ which represents $3.9 \mathrm{~g} \mathrm{~kg}^{-1}$ in the surface $0-10 \mathrm{~cm}$ when compared with the $10-20 \mathrm{~cm}$ depth. Our data agrees with previous research that documented higher amounts of POM at the surface compared to below surface (Mikha et al., 2010 and 2017). In this study, soil 


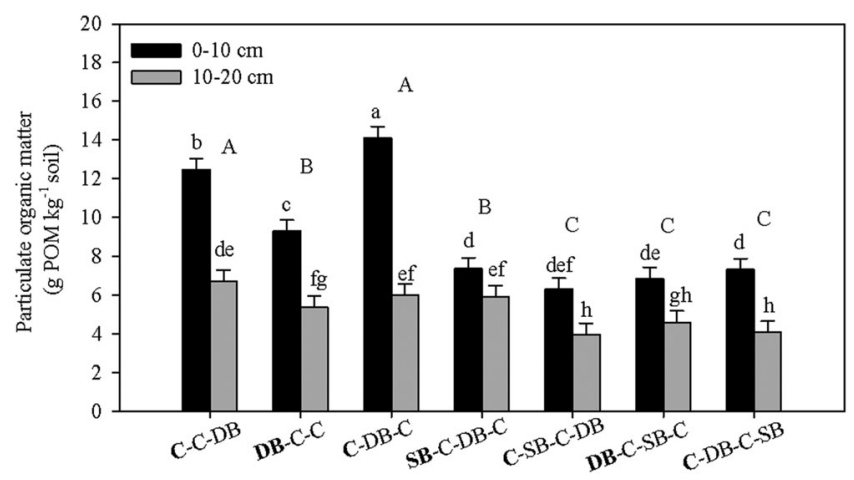

F I G U R E 6 Particulate organic matter (POM) at 0-10 and 10$20 \mathrm{~cm}$ depth (tillage $\times$ rotation phase interaction) influenced by crop rotations with different rotation phases and cropping frequency: dry bean (DB), corn (C), sugar beet (SB) and tillage practices (moldboard plow, MP; strip tillage, ST; and no-tillage, NT). The lowercase letters represent (ANOVA) significant $(P<.05)$ differences between depths. The uppercase letters represent (ANOVA) significant $(P<.05)$ differences among rotation phases. The error bars represent the standard deviation among the means. The bolded crop represents the crop phase that was planted in 2018 before 2019 spring soil sampling

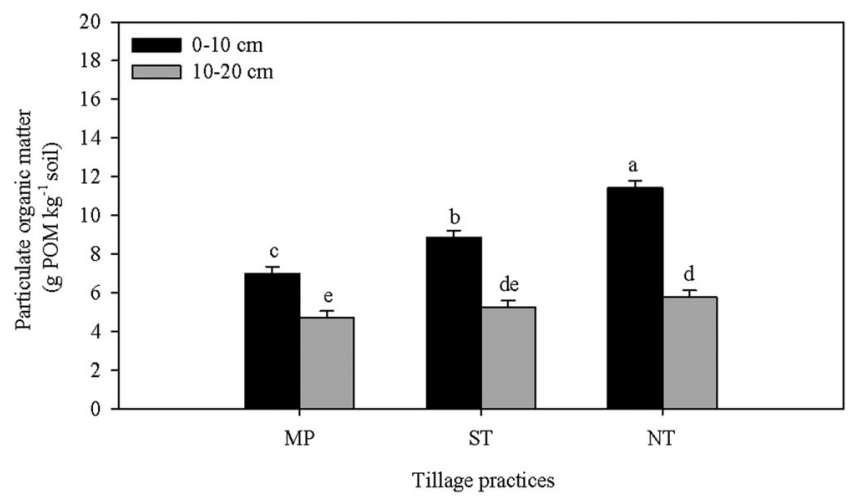

F I G U R E 7 Particulate organic matter (POM) at 0-10 and 10$20 \mathrm{~cm}$ depth average across crop rotations (tillage $\times$ depth interaction) influenced by tillage practices (moldboard plow, MP; strip tillage, ST; and no-tillage, NT). The lowercase letters represent (ANOVA) significant $(P<.05)$ differences among tillage practices. The error bars represent the standard deviation among the means

POM was influenced by tillage treatment at both depths studied (Figure 7). At the $0-10 \mathrm{~cm}$ depth, soil POM was greater with NT by approximately $64 \%$ which represents $4.4 \mathrm{~g} \mathrm{~kg}^{-1}$ and with ST by approximately $27 \%$ which represents $1.8 \mathrm{~g} \mathrm{~kg}^{-1}$, when compared with POM associated with MP. The soil inversion and redistribution of surface plant residue to the $30-\mathrm{cm}$ depth with MP could contribute to the significant reduction of soil POM at the surface layer in MP compared with NT and ST treatments. At depth of $10-20 \mathrm{~cm}$, the differences in soil POM among tillage practices were less pronounced where it was greater with NT by $8.5 \%\left(1.1 \mathrm{~g} \mathrm{~kg}^{-1}\right)$, when compared with MP and the ST

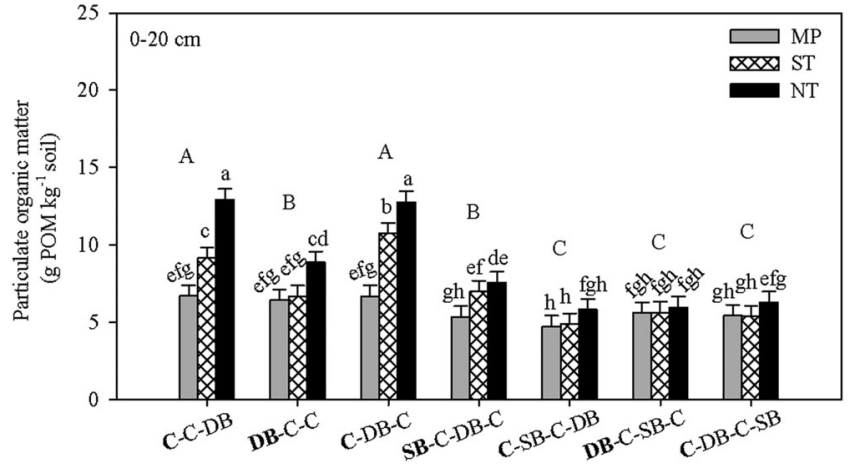

F I G U R E 8 Particulate organic matter (POM) at 0-20 cm depth (tillage $\times$ rotation phase interaction) influenced by crop rotations with different rotation phases and cropping frequency: dry bean (DB), corn (C), sugar beet (SB) and tillage practices (moldboard plow, MP; strip tillage, ST; and no-tillage, NT). The lowercase letters represent (ANOVA) significant $(P<.05)$ differences among tillage practices. The uppercase letters represent (ANOVA) significant $(P<.05)$ differences among rotation phases. The error bars represent the standard deviation among the means. The bolded crop represents the crop phase that was planted in 2018 before 2019 spring soil sampling

treatment was in-between. Higher amounts of POM associated with NT and ST could be related to reduce soil disturbance and maintained corn residue, at the 3-yr rotation, when compared with MP. The MP operation regularly disturbs the soil and mixed the plant residue within the plow layer that could enhance residue decomposition. Our data agrees with Mikha et al. (2013) where they conclude that the MP caused a redistribute of surface residue within the plow layer in addition to the mechanical breakup of crop residue that may enhance POM oxidation. The inclusion of $\mathrm{SB}$ in the 4-yr rotation further contributed to the reduction of POM due to the soil disturbance during SB planting and harvesting operations.

At the 0-20 cm depth, soil POM was significantly influenced by tillage $(P=.0012)$, crop rotations $(P<.0001)$ and tillage $\times$ crop rotations $(P<.0001)$ interaction (Figure 8). Soil POM was higher with NT by approximately $47 \%\left(5.5 \mathrm{~g} \mathrm{~kg}^{-1}\right)$, and ST, by approximately $17 \%(2.4 \mathrm{~g}$ $\mathrm{kg}^{-1}$ ), compared with POM associated with MP. The sampling depth of 0-20 cm which was shallower than the MP operation as the surface residue were buried up to 30-cm depth could contribute to the significant differences in POM between NT and ST when compared with MP. In general, the influence of tillage and crop rotations on soil $\mathrm{POM}$, at $0-20 \mathrm{~cm}$ was observed to have a similar trend to the POM observed at the $0-10 \mathrm{~cm}$ depth (Figure 5), but with different magnitude. The dilution effect associated with the sampling depth (e.g. $0-10$ vs. $0-20 \mathrm{~cm}$ ) could reduce the magnitude and the influence of different management practices on the measured parameters. Therefore, sampling the soil with small increments to evaluate some 
soil parameters is important to capture the influence of management practices on soil health. Soil POM amount was found to be influenced by tillage and crop rotation contrary to the other properties presented in this study including crop yield where they were influenced by crop rotation, but not tillage. The POM results, observed in this study, could indicate the POM sensitivity to short-term changes in managements. This observation was supported by previous research documented that POM could represent the most recent plant residue decomposition that had been added through the recent crop residue ( $\mathrm{Bu}$ et al., 2015; Cambardella \& Elliott, 1993; Li et al., 2018).

\section{4 | CONCLUSIONS}

Twelve years of crop rotation with different cropping frequency and crop type significantly influenced crop yield and soil chemical properties. Tillage practices showed no effect on soil chemical properties. The soil POM was significantly influenced by tillage and crop rotation indicating that POM is sensitive to changes in management. The data generated from this study partially supported our hypothesis as crop yield and soil chemical properties were influenced by previous crop phase, but not by tillage or $\mathrm{CF}$, while sugar beet yield was influenced by tillage practices at $P=.113$. However, POM results supported our hypothesis where POM was significantly influenced by tillage, $\mathrm{CF}$, and crop phase in rotation. The data generated by this study could be considered a baseline for future measurements to evaluate the changes in soil properties as influenced by management decisions of this study site. Overall, alternative management strategies need to be implemented to enhance SOM, decrease soil degradation, improve soil properties, and maintain land sustainability in this study site that include sugar beet and dry bean.

\section{ACKNOWLEDGMENT}

We would like to thank USDA-NIFA Hatch project NEB21-177, accession number 1015698 for supporting this project.

\section{O R C I D}

Maysoon M. Mikha (1) https://orcid.org/0000-0003-2264-

1661

Gary W. Hergert (1) https://orcid.org/0000-0001-6944-6199

Bijesh Maharjan (1) https://orcid.org/0000-0002-4728-7956

\section{RE F E RE N C ES}

Alhameid, A., Ibrahim, M., Kumar, S., Sexton, P., \& Schumacher, T. E. (2017). Soil organic carbon changes impacted by crop rotational diversity under no-till farming in South Dakota, USA. Soil
Science Society of America Journal, 81, 868-877. https://doi.org/10. 2136/sssaj2016.04.0121

Alves, L. A., Denardin, L. G. D. O., Martins, A. P., Anghinoni, I., Carvalho, P. C. D. F., \& Tiecher, T. (2019). Soil acidification and P, K, $\mathrm{Ca}$ and $\mathrm{Mg}$ budget as affected by sheep grazing and crop rotation in a long-term integrated crop-livestock system in southern Brazil. Geoderma, 351, 197-208. https://doi.org/10.1016/j.geoderma.2019. 04.036

Arvidsson, J., Bolenius, E., \& Cavalieri, K. M. V. (2012). Effects of compaction during drilling on yield of sugar beet (Beta vulgaris L.). European Journal of Agronomy, 39, 44-51. https://doi.org/10.1016/ j.eja.2012.01.007

Afshar, R. K., Nilahyane, A., Chen, C., He, H., Stevens, W. B., \& Iversen, W. M. (2019). Impact of conservation tillage and nitrogen on sugarbeet yield and quality. Soil and Tillage Research, 191, 216223. https://doi.org/10.1016/j.still.2019.03.017

Bowren, K. E., Biederbeck, V. O., Biorge, H. A., Brandt, S. A., Goplen, B. P., Henry, J. L., ... McLean, L. A. (1995). Soil improvement with legumes. Saskatchewan Agriculture and Food. Retrieved from https://www.saskatchewan.ca/business/agriculture-naturalresources-and-industry/agribusiness-farmers-and-ranchers/ crops-and-irrigation/soils-fertility-and-nutrients/soilimprovements-with-legumes (accessed 3 Aug. 2019).

Brereton, J. C., McGowan, M., \& Dawkins, T. C. K. (1986). The relative sensitivity of spring barley, spring field beans, and sugar beet crops to soil compaction. Field Crops Research, 13, 223-237. https://doi. org/10.1016/0378-4290(86)90024-9

Bu, R., Lu, J., Ren, T., Liu, B., Li, X., \& Cong, R. (2015). Particulate organic matter affects soil nitrogen mineralization under two crop rotation systems. Plos One, 10, e0143835. https://doi.org/10.1371/ journal.pone.0143835.

Castro, G. S. A., Crusciol, C. A. C., Calonego, J. C., \& Rosolem, C. A. (2015). Management impacts on soil organic matter of tropical soils. Vadose Zone Journal, 14, 1-8. https://doi.org/10.2136/vzj2014. 07.0093

Cambardella, C. A., \& Elliott, E. T. (1993). Carbon and nitrogen distribution in aggregates from cultivated and native grassland soils. Soil Science Society of America Journal, 57, 1071-1076. https://doi. org/10.2136/sssaj1993.03615995005700040032x

Cambardella, C. A., Gajda, A. M., Doran, J. W., Wienhold, B. J., \& Kettler, T. A. (2001). Estimation of particulate and total organic matter by weight loss-on-ignition. In R. Lal (Ed.), et al. Assessment methods for soil carbon (pp. 349-359). Boca Raton, FL: Lewis Publishers, CRC Press.

Cerdan, C., Govers, G., Le Bissonnais, Y., Van Oost, K., Poesen, J., Saby, N. P. A., \& Dostal, T. (2010). Rates and spatial variations of soil erosion in Europe: A study based on erosion plot data. Geomorphology, 122, 167-177. https://doi.org/10.1016/j.geomorph. 2010.06.011

Combs, S. M., Denning, J. L., \& Frank, K. D. (1998). Sulfate-sulfur. In J. R. Brown (Ed.), Recommended chemical soil test procedures for the North Central Region (pp. 35-40). North Central Publication No. 221 (Revised). Columbia, MO: University of Missouri Ag. Exp. Station.

Curtin, D., Beare, M. H., \& Hernandez-Ramirez, G. (2012). Temperature and moisture effect on microbial biomass and soil organic matter mineralization. Soil Science Society of America Journal, 76, 2055-2067. https://doi.org/10.2136/sssaj2012.0011

Daberkow, S., Payne, J., \& Schepers, J. (2008). Comparing continuous corn and corn-soybean cropping systems. Western Economic 
Forum. Retrieved from https//naldc.nal.usda.gov (accessed 2 Aug. 2019).

Eckert, F. R., Kandel, H. J., Johnson, B. L., Rojas-Cifuentes, G. A., Deplazes, C., Vander Wal, A. J., \& Osorno, J. M. (2011). Seed yield and loss of dry bean cultivars under conventional and direct harvest. Agronomy Journal, 103, 129-136. https://doi.org/10.2134/ agronj2010.0199

Evens, R. G., Stevens, W. B., \& Iversen, W. M. (2009). Development of strip tillage on sprinkler irrigated sugarbeet. Applied Engineering in Agriculture, 26, 59-69. https://doi.org/10.13031/2013.29476

Frank, K., Beegle, D., \& Denning, J. (1998). Phosphorus. In J. R. Brown (Ed.), Recommended chemical soil test procedures for the North Central Region (pp. 21-29). North Central Regional Publication No. 221 (revised). Columbia, MO: University of Missouri Ag. Exp. Station.

Franc, G. D., Harrveson, R. M., Kerr, E. D., \& Jacobsen, B. J. (2001). Disease management. In R. G. Wilson (Ed.), Sugarbeet production guide (pp. 131-153). Lincoln, NE: Univ. of Nebraska, NU Cooperative Extension.

Gaussoin, R. E., Kappler, B. F., Klein, R. V., Knezevic, S. Z., \& Lyon, D. J. (2005). Guide for weed management in Nebraska. Lincoln, NE: University of Nebraska Cooperative Extension. Retrieved from http://digitalcommons.unl.edu/cgi/viewcontent. cgi?article $=2794 \&$ context=extensionhist

Geldeman, R. H., \& Beegle, D. (1998). Nitrate-Nitrogen. In J. R. Brown (Ed.), Recommended chemical soil test procedures for the North Central Region (pp. 17-20). North Central Publication No. 221 (Revised). Columbia, MO: University of Missouri Ag. Exp. Station.

Götze, P., Rücknagel, J., Jacobs, A., Märländer, B., Koch, H. J., Holzweißig, B., \& Christen, O. (2016). Sugar beet rotation effects on soil organic matter and calculated humus balance in Central Germany. European Journal of Agronomy, 76, 198-207. https://doi. org/10.1016/j.eja.2015.12.004

Gregorich, E. G., Cartter, M. R., Angers, D. A., Monreal, C. M., \& Ellert, B. H. (1994). Towards a minimum data set to assess soil organic matter quantity in Agricultural soils. Canadian Journal of Soil Science, 74, 367-385. https://doi.org/10.4141/cjss94-051

Groskopf, J., Creech, C., Hergert, G., Luebbe, M., Santra, D., Stephenson, M., \& Stone, G. (2017). Agriculture in Nebraska Panhandle. Retrieved from http://extensionpublications.unl.edu/assets/ pdf/ec864.pdf (Accessed 21 Feb. 2020).

Gurr, G. M., Lu, Z., Zheng, X., Xu, H., Zhu, P., Chen, G., \& Catindig, J. L. (2016). Multi-country evidence that crop diversification promotes ecological intensification of agriculture. Nature Plants, 2, https://doi.org/10.1038/nplants.2016.14

Haruna, S., \& Nkongolo, N. V. (2019). Tillage, cover crop and crop rotation effects on selected soil chemical properties. Sustainability, 11, 2770. https://doi.org/10.3390/su11102770

Halvorson, A. D., \& Hartman, G. P. (1984). Reduce seedbed tillage effects on irrigated sugarbeet yield and quality. Agronomy Journal, 76, 603-606. https://doi.org/10.2134/agronj1984. $00021962007600040023 x$

Havlin, J. L., Kissel, D. E., Maddux, L. D., Claassen, M. M., \& Long, J. H. (1990). Crop rotation and tillage effects on soil organic carbon and nitrogen. Soil Science Society of America Journal, 54, 448-542. https://doi.org/10.2136/sssaj1990.03615995005400020026x

Hergert, G. W. (2012). Sugarbeet nutrient management. UNL NebGuide G1459. Lincoln, NE: University of Nebraska Extension.
Hergert, G. W., \& Schild, J. A. (2013). Fertilizer management for dry edible beans. UNL NebGuide G1713. UNL Ext. Lincoln, NE: University of Nebraska Extension.

High Plains Regional Climate Center. (2020). University of NebraskaLincoln. Retrieved from https://hprcc.unl.edu/ Retrieved from (accessed 21 Mar. 2019).

Hungria, M., Franchini, J. C., Brandao-Junior, O., Kaschuk, G., \& Souza, R. A. (2009). Soil microbial activity and crop sustainability in a long-term experiment with three soil-tillage and two croprotation systems. Applied Soil Ecology, 42, 288-296. https://doi. org/10.1016/j.apsoil.2009.05.005

Karlen, D. L., Hurley, E. G., Andrews, S. S., Cambardella, C. A., Meek, D. W., Duffy, M. D., \& Mallarino, A. P. (2006). Crop rotation effects on soil quality at three northern corn/soybean belt locations. Agronomy Journal, 98, 484-495. https://doi.org/10.2134/ agronj2005.0098

Karlen, D. L., Wollenhaupt, N. C., Erbach, D. C., Berry, E. C., Swan, J. B., Eash, N. S., \& Jordahl, J. L. (1994). Crop residue effects on soil quality following 10-years of no-till corn. Soil and Tillage Research, 31, 149-167. https://doi.org/10.1016/0167-1987(94)90077-9

Khan, Q. A., \& McVay, K. A. (2014). Impact of tillage, irrigation method, and nitrogen rate on sugar beet productivity. Agronomy Journal, 106, 1717-1721. https://doi.org/10.2134/agronj14. 0081

Land, M., Haddaway, N. R., Hedlund, K., Jørgensen, H. B., Kätterer, T., \& Isberg, P-E. (2017). How do selected crop rotations affect soil organic carbon in boreo-temperate systems? A systematic review protocols. Environmental Evidence, 6, https://doi.org/ 10.1186/s13750-017-0086-y

Larney, F. J., Pearson, D. C., Blackshaw, R. E., \& Lupwayi, N. Z. (2017). Soil changes over $12 \mathrm{yr}$ of conventional vs. conservation management on irrigated rotations in southern Alberta. Canadian Journal of Soil Science, 97, 249-265.

Li, J., Ramirez, G. H., Kiani, M., Quideau, S., Smith, E., Janzen, H., \& Puurveen, D. (2018). Soil organic matter dynamics in long-term temperate agroecosystems: Rotation and nutrient addition effects. Canadian Journal of Soil Science, 98, 232-245. https://doi.org/10. 1139/cjss-2017-0127

Li, L., Larney, F. J., Angers, D. A., Pearson, D. C., \& Blackshaw, R. E. (2015). Surface soil quality attributes following 12 years of conventional and conservation management on irrigated rotations in southern Alberta. Soil Science Society of America Journal, 79, 930942. https://doi.org/10.2136/sssaj2015.02.0051

Lindsay, W. L., \& Norvell, W. A. (1978). Development of a DTPA test for zinc, iron, manganese, and copper. Soil Science Society of America Journal, 42, 421-428. https://doi.org/10.2136/sssaj1978. 03615995004200030009x

Maltas, A., Charles, R., Jeangros, B., \& Sinaj, S. (2013). Effect of organic fertilizers and reduce-tillage on soil properties, crop nitrogen response and crop yield: Results of a 12-years experiment in Changins, Switzerland. Soil and Tillage Research, 126, 11-18. https://doi.org/10.1016/j.still.2012.07.012

Manjula, N., Stecker, J., \& Sun, Y. (2006). Soil testing in Missouri, a guide for conducting soil tests in Missouri. Missouri Coop. Ext. Service, Univ. of Missouri-Lincoln Univ.

McDaniel, M., Tiemann, L., \& Grandy, A. (2014). Does agricultural crop diversity enhance soil microbial biomass and organic matter dynamics? A meta-analysis. Ecological Applications, 24, 560-570. https://doi.org/10.1890/13-0616.1 
McDaniel, M., Grandy, A., Tiemann, L., \& Weintraub, M. (2016). Eleven years of crop diversification alters decomposition dynamics of litter mixtures incubated with soil. Ecosphere, 7, https://doi. org/10.1002/ecs2.1426

McLean, E. O. (1982). Soil pH and lime requirement. In A. L. Page (Ed.), Methods of soil analysis, Part 2. Chemical and microbiological properties. Agronomy Monograph No. 9 (2nd ed., pp. 199-209). Madison, WI: Soil Science Society of America.

Mikha, M. M., Benjamin, J. G., Stahlman, P. W., \& Geier, P. W. (2014). Remediation/Restoration of degraded soil: I. Impact on soil chemical properties. Agronomy Journal, 106, 252-260. https://doi.org/ 10.2134/agronj2013.0278

Mikha, M. M., Benjamin, J. G., Vigil, M. F., \& Nielson, D. C. (2010). Cropping intensity impacts on soil aggregation and carbon sequestration in the central Great Plains. Soil Science Society of America Journal, 74, 1712-1719. https://doi.org/10.2136/sssaj2009.0335

Mikha, M. M., Hergert, G. W., Benjamin, J. G.. Jabro, J. D., \& Nielsen, R. A. (2017). Soil organic carbon and nitrogen in long-term manure management system. Soil Science Society of America Journal, 81, 153-165. https://doi.org/10.2136/sssaj2016.04.0107

Mikha, M. M., Vigil, M. F., \& Benjamin, J. G. (2013). Long-term tillage impacts on soil aggregation and carbon dynamics under wheatfallow in the central Great Plains. Soil Science Society of America Journal, 77, 594-605. https://doi.org/10.2136/sssaj2012.0125

Mikha, M. M., Vigil, M. F., Liebig, M. A., Bowman, R. A., McConkey, B., Deibert, E. J., \& Pikul, Jr, J. L. (2006). Cropping system influences on soil chemical properties and soil quality in the Great Plains. Renewable Agriculture and Food Systems, 21, 26-35. https: //doi.org/10.1079/RAFS2005123

Obour, A. K., Mikha, M. M., Holman, J. D., \& Stahlman, P. W. (2017). Changes in soil surface chemistry after fifty years of tillage and nitrogen fertilization. Geoderma, 308, 46-53. https://doi.org/10. 1016/j.geoderma.2017.08.020

Ohtonen, R., Aikio, S., \& Vare, H. (1997). Ecological theories in soil biology. Soil Biology \& Biochemistry, 29, 1613-1619.

Pavlista, A. D., Hergert, G., Santra, D. K., \& Schild, J. A. (2013). Improving bean harvest with gibberellic acid. HortTechnology, 23, 282-287. https://doi.org/10.21273/HORTTECH.23.3.282

Russelle, M. P., \& Birr, A. S. (2004). Large-scale assessment of symbiotic dinitrogen fixation by crops. Agronomy Journal, 96, 1754-1760. https://doi.org/10.2134/agronj2004.1754

SAS Institute Inc. (2006). SAS/STAT User's Guide, Version 9.2. Cary, NC: SAS Institute, Inc.

Shapiro, C. A., Ferguson, R. B., Wortmann, C. S., Maharjan, B., \& Krienke, B. (2019). Nutrient management suggestions for corn. UNL EC117. NE Ext. Lincoln, NE: University of Nebraska Extension.

Sistani, K. R., Simmons, J. R., Warrem, J. G., \& Higgins, S. (2017). Nitrogen source and application method impact on corn yield and nutrient uptake. Journal of Plant Nutrition, 40, 878-889. https: //doi.org/10.1080/01904167.2016.1262410

Skjemstad, J. O., \& Baldock, J. A. (2007). Total and organic carbon. In M. R. Carter \& E. G. Gregorich (Eds.), Soil sampling and methods of analysis (pp. 225-237). Boca Raton, FL: CRC Publishers.

Smith, J. A. (2004). Harvest. In H. F. Schwartz, M. A. Brick, R. M. Harveson, \& G. D. Franc (Eds.), Dry bean production \& integrated pest management (2nd ed., pp. 59-69). Colorado State Univ. Reg. Bul. 562A. Fort Collins: Colorado State University.

Smith, J. A., Yonts, C. D., Biere, D. A., \& Rath, M. D. (1995). Field operation energy used for a corn-dry-edible-bean-sugarbeet rotation. Applied Engineering in Agriculture, 11, 219-224. https://doi.org/10. 13031/2013.25731

Smith, R. G., Gross, K. L., \& Robertson, G. (2008). Effects of crop diversity on agroecosystem function: Crop yield response. Ecosystems, 11, 355-366. https://doi.org/10.1007/s10021-008-9124-5

Stevens, W. B., Evans, R. G., Jabro, J. D., \& Iversen, W. M. (2010). Nitrogen availability for sugarbeet affected by tillage system and sprinkler irrigation method. Agronomy Journal, 102, 1745-1752. https://doi.org/10.2134/agronj2010.0122

Tarkalson, D. D., Bjorneberg, D. L. Z., \& Moore, A. (2012). Effects of tillage system and nitrogen supply on sugarbeet production. Journal of Sugarbeet Research, 49, 79-102. https://doi.org/10.5274/jsbr. 49.3.79

Tarkalson, D. D., \& King, B. A. (2017). Effects of tillage and irrigation management on sugarbeet production. Agronomy Journal, 109, 2396-2406. https://doi.org/10.2134/agronj2016.09.0530

Tiecher, T., Calegari, A., Caner, L., \& Rheinheimer, D. S. (2017). Soil fertility and nutrient budget after 23-years of different soil tillage systems and winter cover crops in a subtropical Oxisol. Geoderma, 308, 78-85. https://doi.org/10.1016/j.geoderma.2017.08.028

Warncke, D., \& Brown, J. R. (1998). Potassium and other basic cations. In J. R. Brown (Ed.), Recommended chemical soil test procedures for the North Central Region (pp. 31-33). North Central Regional Publication No. 221 (revised). Columbia, MO: University of Missouri Ag. Exp. Station.

Whitney, D. A. (1998a). Micronutrients: Zinc, iron, manganese, and copper. In J. R. Brown (Ed.), Recommended chemical soil test procedures for the North Central Region (pp. 41-44). North Central Regional Publication No. 221 (revised). Columbia, MO: University of Missouri Ag Exp. Station.

Whitney, D. A. (1998b). Soil salinity. In J. R. Brown (Ed.), Recommended chemical soil test procedures for the North Central Region (pp. 59-60). North Central Regional Publication No. 221 (revised). Columbia, MO: University of Missouri.

Wilson, R. G. (2013). Crop rotation. In R. G. Wilson (Ed.), Sugarbeet production guide (pp. 25-26). Lincoln, NE: Univ. of NebraskaLincoln Extension.

Withers, P. J., \& Lord, E. I. (2002). Agricultural nutrient inputs to rivers and ground waters in the UK: Policy, environmental management and research needs. Science of the Total Environment, 282, 9-24. https://doi.org/10.1016/S0048-9697(01)00935-4
How to cite this article: Mikha MM, Hergert
GW, Qiao X, Maharjan B. Soil chemical properties after 12 years of tillage and crop rotation. Agronomy Journal. 2020;112:4395-4406. https://doi.org/10.1002/agj2.20281 